\title{
Testing of Volatile Oils Activity Extracted from Different Medicinal Plants Against Some Fungi Isolated from Different Sources
}

\author{
Hadeel A. AL-Ameri \\ Department of Biology, College of sciences, University of Mosul, Mosul, Iraq \\ E-mail: hadeelahmed.mu@gmail.com
}

(Received April 10, 2021; Accepted June 15, 2021; Available online August 28, 2021)

DOI: 10.33899/edusj.2000.168652, ( ) 2021, College of Education for Pure Science, University of Mosul.

This is an open access article under the CC BY 4.0 license (http://creativecommons.org/licenses/by/4.0/).

\begin{abstract}
Volatile oil extracted from Salvia officinalis showed significantly more effective e against growth of $T$. rubrum isolated from ulceration otitis externa with inhibition significant percentage $96.42 \%$ in concentration $1 / 25$ then the concentration $1 / 50$ with inhibition percentage $95.83 \%$, two concentrations $1 / 75$ and $1 / 100$ showed low effects which inhibited fungal growth in percentage $89.28 \%$ and $81.54 \%$ respectively, While the volatile oil extracted from Zingiber officinale showed inhibited effect in percentage $92.26 \%$ in concentration $1 / 25$ and $82.73 \%$ in concentration $1 / 50$; The inhibition percentage was $79.76 \%$ and $77.97 \%$ in concentration $1 / 75$ and $1 / 100$ respectively. Volatile oil extracted from leaves of Apium graveolens was significantly more effective in concentration 1/25 then the volatile oil extracted from Zingiber officinale in the same concentration with a significant inhibition percentage $85.11 \%$ so volatile oil of leaves of Mentha piperita in concentration $1 / 25$ with a significant inhibition percentage $81.54 \%$ and the concentration 1/100 from volatile oil of leaves of Mentha piperita Lower of all concentration inhibition of fungal growth above with inhibition percentage $70.23 \%$.

Volatile oils extracted from Salvia officinalis was more significant effect against growth of yeast $C$. albicans isolated from ulceration otitis externa so the inhibition percentage was $85.11 \%$ followed with volatile oil of leaves of Apium graveolens with percentage $80.35 \%$ in concentration $1 / 50$ then volatile oil of leaves of Mentha piperita with inhibition percentage $79.16 \%$ in the concentration 1/25 while inhibition percentage of volatile oil extracted from Salvia officinalis ranged between $79.76 \%$ and $69.64 \%$, While volatile oil of leaves of Apium graveolens inhibition percentage between $78.57 \%$ and $70.23 \%$ respectively in concentrations $1 / 25,1 / 100$; Volatile oil of Zingiber officinale was lower effect which inhibited fungal growth with percentage $78.57 \%$ and $61.30 \%$ in higher and lower concentrations respectively, While different volatile oils extracts shows a different inhibition effects against T. Mantagrophytes isolated from skin scraping, So volatile oil extracted from leaves of Mentha piperita showed more effective in concentration $1 / 25$ with inhibition percentage $97.16 \%$ then volatile oil extracted from Salvia officinalis with percentage $77.38 \%$ in same concentration, There were no significant difference in concentration $1 / 25$ and $1 / 50$ of volatile oil extracted from Zingiber officinale with inhibition percentage $73.80 \%$ for both concentrations and volatile oil of leaves of Apium graveolens was less effective which inhibited T. Mantagrophytes in inhibition percentage $69.04 \%$ and $64.88 \%$ at the concentrations of $1 / 25$ and $1 / 50$ respectively. There was no significant difference between concentrations $1 / 75$ and $1 / 100$ with a percentage of $59.52 \%$ for both of them.
\end{abstract}

Keywords: Salvia officinalis, Zingiber officinale, Mentha piperita, T. Mantagrophytes, C. albicans, $T$. rubrum 
Journal of Education and Science (ISSN 1812-125X), Vol: 30, No: 3, 2021 (21-33)

Special Issue for Proceeding of $3^{\text {rd }}$ National (1st international conference of biology) (ICBSUM 2021) 5, 6 July College of Education for Pure Science, University of Mosul, Mosul, Iraq.

اختبار فعالية الزيوت الطيارة المستخلصة من نباتات طبية مختلفة على بعض الفطريات المرضية

هايل احمد العامري

جامعة الموصل/كلية العلوم/قسم علوم الحياة

الخلاصة

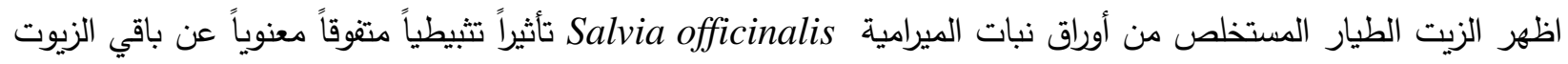

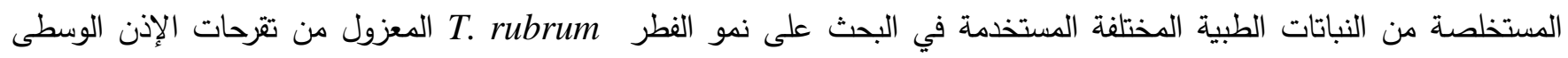

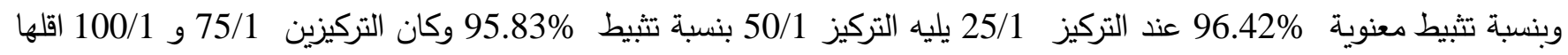
تأثيراً إذ ثطا نمو الفطر بنسبة

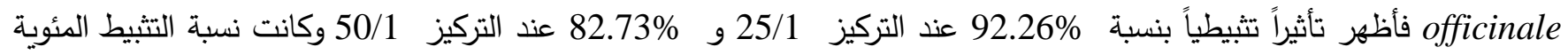
79.76\% و 77.79\% عند التركيزين 75/1 و 100/1 على التوالي؛ وتفوق الزيت الطيار الدستخلص من أوراق نبات الكرفس Apium graveolens نسبة التثبط المئوية 85.11\% كنلك الزيت الطيار لأوراق نبات النعناع عند نفس التركيز بنسبة تثبيط مئوية بلغت

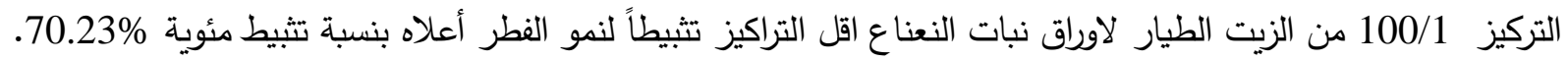

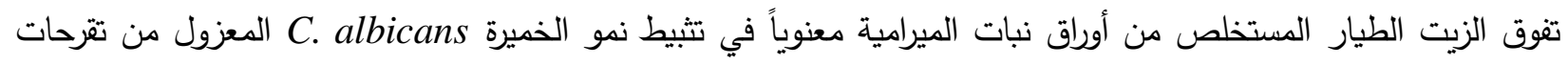

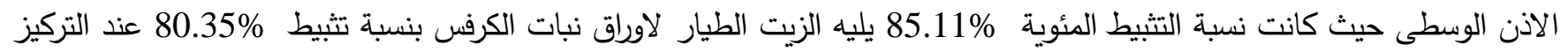
25/1 ثم الزيت الطيار لاوراق نبات النعناع بنسبة تنبيط 79.76\% عند نفس التركيز اعلاه في حين تراوحت نسبة التثبيط المئوية للزيت الطيار المستخلص من اوراق نبات الميرامية بين 79.76\% و 78.57\% 69.64\% لاعلى التراكيز واقلها على التوالي، اما الزيت الطيار

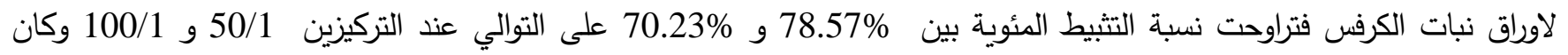
الزيت الطيار المستخلص من ثمار نبات الزنجبيل اقلها تاثيراً اذ ثبط نمو الفطر 61.30\% عند اعلى واقل التراكيز على التوالي.

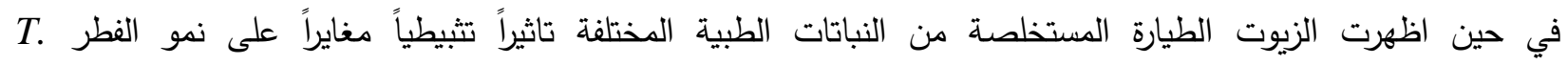

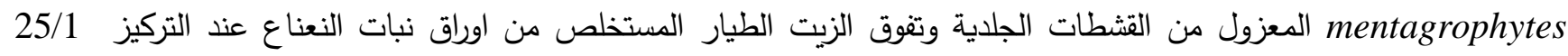

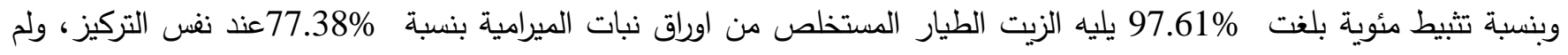

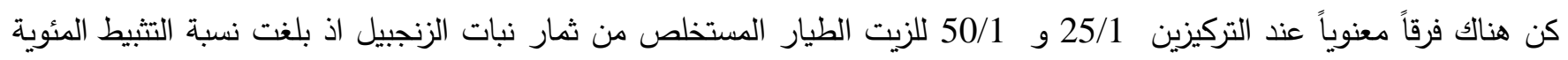
73.80\% لكلا التركيزين وكان الزيت الطيار لاوراق نبات الكرفس اقلها تاثيراً اذ ثبط نمو الفطر

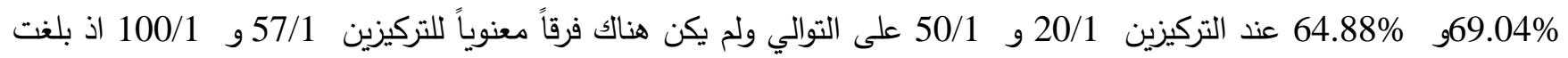
نسبة التثبيط المئوية 59.52\% لكل منهما.

Zingiber officinale, Mentha piperita, T. Mantagrophytes, C. albicans, T. rubrum الكلمات الففتاحية 
Journal of Education and Science (ISSN 1812-125X), Vol: 30, No: 3, 2021 (21-33)

Special Issue for Proceeding of $3^{\text {rd }}$ National (1 ${ }^{\text {st }}$ international conference of biology) (ICBSUM 2021) 5, 6 July

College of Education for Pure Science, University of Mosul, Mosul, Iraq.

\section{Introduction}

Skin infections are a high percentage of skin diseases in humans, especially in warm areas where the environment is suitable for growth of fungi as well as the availability of moisture, heat and keratin materials [1], Skin fungi infect the surface layer of the body so it is Keratinophilic tissue [2] Which includes hair, skin and nails as keratin is the main source of nutrition [3], Filamentous dermatophytes produces many enzymes such as pyrotechnics, keratinase, elastase, lipase, phospholipids, amylase and DNA ase [4], and carbon and nitrogen [5]. Dermatophytes differ from one species to another in their composition to these enzymes [6] [7]. The term Tinea is refers to infections caused by dermatophytes which it's mean Ring worm [1].

Candida is an opportunistic pathogenic yeast, the species Candida albicans is a natural human microbiota fungus. Although candidiasis is commonly regarded as a harmless commensal in healthy people, it may become overgrown and cause a variety of complications in the host, ranging from localized superficial infections to systemic life-threatening disseminated candidiasis like Oral Candidiasis, Vaginal Candidiasis, and Ears Candidiasis [8]. The ability of C. albicans to form biofilms, a densely packed population of cells that can develop on both abiotic and biotic substrates such as implanted medical devices and mucosal surfaces, is a significant virulence factor [9].

C. albicans infections associated with high morbidity and mortality rates, making them a significant clinical challenge [10] [11]. These infections have recently increased dramatically due to the increase in the incidence of immunodeficiency caused by Irradiation, Chemotherapy, Cancer, Diabetes and taking immunosuppressive treatments and over-taking treatments without medical advice and Acuired Immuno Deficiency Syndrome [12].

Due to the increase in resistance to the antifungal agents used to treat various fungi infections [13]. and the possession of the antifungal side effects on because of their toxicity to the mammalian cells [14], it was necessary to find alternatives to the antifungal agents that have high effectiveness against pathogenic fungi and are safe to use to eliminate the characteristic of antibiotic resistance in pathogenic fungi such as volatile oil extracted from some medicinal plants, this is the aim of this study. 
Journal of Education and Science (ISSN 1812-125X), Vol: 30, No: 3, 2021 (21-33)

Special Issue for Proceeding of $3^{\text {rd }}$ National (1 ${ }^{\text {st }}$ international conference of biology) (ICBSUM 2021) 5, 6 July

College of Education for Pure Science, University of Mosul, Mosul, Iraq.

\section{Research Methods}

\section{Medicinal plants used in research and extraction of volatile oil from its parts and sterilized}

Four medical plants were selected to extract the volatile oil from their parts and study their affectivity, Which are the leaves of Apium graveolens, Salvia officinalis and Zingiber officinale fruits displayed in local markets of Mosul city, While Mentha piperita leaves was obtained from the Gardens of Mosul university, the plant samples were classified in the herbivores of college of Science/Biology department /University of Mosul, Volatile oil attended from the parts of plants was studied by steam distillation.

dried plant samples amount $500 \mathrm{~g}$. of were crushed and placed in the drip of the distillation device. The distillation process was carried out, the oil was collected and dried using anhydrous calcium chloride. The samples were preserved at $4^{\circ} \mathrm{C}$ until Procedure the inhibition tests. Then sterilize the extracted oil with $1 \mathrm{~cm}^{3}$ of it in $9 \mathrm{~cm}^{3}$ of Ethylen glycol and sterilization using membrane filters with diameter 0.22 Micron was used to prepare concentrations used in research.

\section{Source of isolates and method of sampling}

Trichophyton mentagrophytes and T. rubrum isolated from Scraps for skin by sterilizing the affected area superficially in ethanol $70 \%$ The edges of the infection were scraped using a sterile scalpel and the peels were taken and cultured on media Sabouraud's Glucose Agar (SGA) For three weeks, the fungi identification according to approved taxonomic keys. Yeast Candida albicans isolated from External ear ulcers with Ear Candidiasis By sterilization of external ear with cotton swab saturated with ethanol $70 \%$ it left to dry and then took a swab of the ear with a sterile cotton swab and cultured on SGA The samples were incubated at $27^{\circ} \mathrm{c}$ for three weeks, the fungi identification according to approved taxonomic keys [15] .

\section{Inhibition test}

Test the inhibitory effect of volatile oils extracted from medicinal plants studied on the growth of fungi T. mentagrophytes and T. rubrum by adding specific sizes of all extracted and sterilized oil to specific sizes of SGA media before hardening after blending well the concentrations $(1 / 25,1 / 50,1 / 75$, $1 / 100) \mathrm{cm}^{3} / \mathrm{cm}^{3}$ were obtained and then poured into sterile Petri dishes with a diameter of $9 \mathrm{~cm}$, After hardening the media take a tablet from the edge of the fungal colony of the fungi studied by the cork 
Journal of Education and Science (ISSN 1812-125X), Vol: 30, No: 3, 2021 (21-33)

Special Issue for Proceeding of $3^{\text {rd }}$ National (1 ${ }^{\text {st }}$ international conference of biology) (ICBSUM 2021) 5, 6 July

College of Education for Pure Science, University of Mosul, Mosul, Iraq.

borer $0.5 \mathrm{~cm}$ diameter and but it in the center of the Petri dish in sterile conditions, Incubate the dishes in an inverted position at $27^{\circ} \mathrm{C}$ until the control dish is filled, The results were calculated by averaging two orthogonal diameter of each fungal colony by three replicates per concentration and each replicate one dish [16].

In C. albicans, inhibitory effect of volatile oils extracted from medicinal plants was tested using Agar Wells Diffusion method [17] [18]. C. albicans was cultured on the medium of the SGA (Thickness of medium $0.5 \mathrm{~cm}$ ) by Streak plating by sterile loop (streaking), and the Wells was made in the plate with a diameter of $0.5 \mathrm{~cm}$ using the cork borer and care should be taken to leave adequate spaces between the Wells to avoid the overlap of inhibition zones, then put $0.5 \mathrm{~cm}^{3}$ from different concentrations of each of the medicinal plants used in the study on the wells by syringe, control wells was filled with distilled water, Incubate the dishes at $27^{\circ} \mathrm{C}$ for $48 \mathrm{~h}$. The results were taken by measuring the diameter of the inhibition zones around the wells. All results were statistically analyzed using the Duncan test to determine the significant differences at a probability level of 0.05 [19].

\section{Results And Discussion}

Table (1) and picture (1) appears that the volatile oil extracted from Mentha piperita leaves significantly exceeded another volatile oils in inhibiting the growth of the fungus T. mentagrophytes The percentage of inhibition was $97.19 \%$ at concentration 1/25 followed by the volatile oil extracted from the leaves of the Salvia officinalis with a percentage $77.38 \%$ of inhibition at the same concentration and then the volatile oil of Zingiber officinale fruit with a percentage of the inhibition of $73.80 \%$ at concentrations $1 / 25$ and $1 / 50$, While the percentage of inhibition was $72.61 \%$ at the concentration of 1/75 for the volatile oil of the Salvia officinalis leaves, while the concentration of 1/50 of the volatile oil for Mentha piperita leaves was affected by a percentage of $69.64 \%$, followed by the concentration $1 / 25$ of the volatile oil for the leaves of the Apium graveolens as the percentage of inhibition was 69.04\% and did not differ significantly from the volatile oil of Zingiber officinale fruit by the inhibition percentage of $67.61 \%$ and $66.66 \%$ at concentrations $1 / 75$ and $1 / 100$ respectively. 
Journal of Education and Science (ISSN 1812-125X), Vol: 30, No: 3, 2021 (21-33)

Special Issue for Proceeding of $3^{\text {rd }}$ National (1 ${ }^{\text {st }}$ international conference of biology) (ICBSUM 2021) 5, 6 July

College of Education for Pure Science, University of Mosul, Mosul, Iraq.

Table 1. Effect of different volatile oils on growth of fungi T. mentagrophytes

\begin{tabular}{|c|c|c|c|}
\hline Type of plant oil & $\begin{array}{c}\text { concentration } \\
\mathrm{cm}^{3} / \mathrm{cm}^{3}\end{array}$ & $\begin{array}{l}\text { Mean of colony } \\
\text { diameter } / \mathrm{cm}^{*}\end{array}$ & $\begin{array}{l}\text { percentage of } \\
\text { inhibition } \%^{* *}\end{array}$ \\
\hline \multirow[t]{4}{*}{ Apium graveolens oil } & $1 / 25$ & 2.6 & $69.04 \mathrm{G}$ \\
\hline & $1 / 50$ & 2.95 & $64.88 \mathrm{~J}$ \\
\hline & $1 / 75$ & 3.4 & $59.52 \mathrm{~N}$ \\
\hline & $1 / 100$ & 3.4 & $59.52 \mathrm{~N}$ \\
\hline \multirow{4}{*}{$\begin{array}{c}\text { Mentha piperita } \\
\text { oil }\end{array}$} & $1 / 25$ & 0.2 & $97.19 \mathrm{~A}$ \\
\hline & $1 / 50$ & 2.55 & $69.64 \mathrm{E}$ \\
\hline & $1 / 75$ & 3.0 & $64.28 \mathrm{~K}$ \\
\hline & $1 / 100$ & 3.1 & $63.09 \mathrm{~L}$ \\
\hline \multirow[t]{4}{*}{ Salvia officinalis oil } & $1 / 25$ & 1.9 & $77.38 \mathrm{~B}$ \\
\hline & $1 / 50$ & 3.2 & $61.90 \mathrm{M}$ \\
\hline & $1 / 75$ & 2.3 & $72.61 \mathrm{D}$ \\
\hline & $1 / 100$ & 2.65 & $68.45 \mathrm{~F}$ \\
\hline \multirow[t]{4}{*}{ Zingiber officinale oil } & $1 / 25$ & 2.2 & $73.80 \mathrm{C}$ \\
\hline & $1 / 50$ & 2.2 & $73.80 \mathrm{C}$ \\
\hline & $1 / 75$ & 2.72 & $67.61 \mathrm{H}$ \\
\hline & $1 / 100$ & 2.8 & $66.66 \mathrm{I}$ \\
\hline Control & 0 & 8.4 & $0.0 \mathrm{~L}$ \\
\hline
\end{tabular}

*: Average values represent an average of three readings.

** : The values that share a single alphabetical letter have no significant difference according to the Duncan test at a probability level of 0.05 .

While the concentration 1/50 of the volatile oil of the leaves of the Apium graveolens showed a disincentive effect of $64.88 \%$ and the concentrations $1 / 75$ and 1/100 for the volatile oil of Mentha piperita leaves with inhibition percentage $64.28 \%$ and $63.09 \%$ respectively, Finally, concentrations $1 / 75$ and 1/100 for the volatile oil extracted from the leaves of the Apium graveolens were the least effective on the growth of T. mentagrophytes with percentage $59.52 \%$ for both of them. 


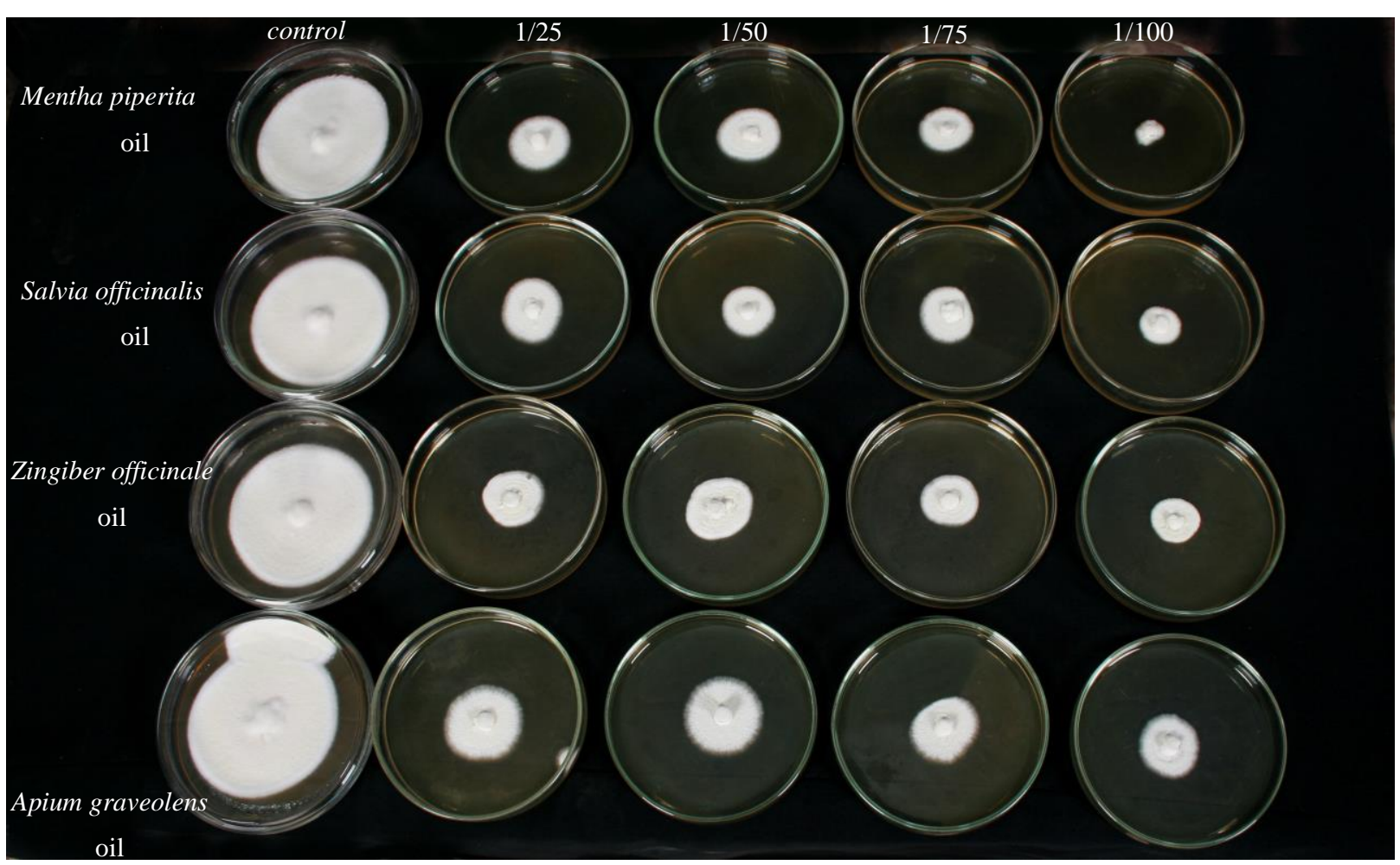

Figure 1. Effect of volatile oil extracted from different medicinal plants with concentrations $(1 / 25$, $1 / 50,1 / 75$ and $1 / 100) \mathrm{cm}^{3} / \mathrm{cm}^{3}$ against $T$. mentagrophytes.

The volatile oil extracted from the leaves of the Salvia officinalis plant showed a significant inhibitory effect on the growth of C. albicans, with inhibition percentage $85.11 \%$ at $1 / 25$ concentration followed by the volatile oil extracted from the leaves of the Apium graveolens and Salvia officinalis leaves by inhibiting $80.35 \%$ and $79.76 \%$, respectively, at 1/50 concentration, volatile oil from Mentha piperita and volatile oil from the leaves of the Apium graveolens inhibiting with percentage $79.16 \%$ and $78.57 \%$, respectively, at 1/25 concentration, Apium graveolens oil did not differ significantly from Zingiber officinale oil at concentration 1/25 and Mentha piperita leaves oil at concentration 1/50 with $77.97 \%$, Followed by Salvia officinalis oil with inhibition percentage $77.38 \%$ at concentration 1/75 and Zingiber officinale oil at concentration $1 / 50$ with inhibition percentage of $75.59 \%$, While Mentha piperita oil and Zingiber officinale oil showed an inhibition percentage $74.04 \%$ and $73.21 \%$ respectively at concentration 1/75, followed by volatile oil of Mentha piperita leaves in concentration 1/100 with inhibition percentage $72.61 \%$ and Apium graveolens oil with inhibition percentage $71.42 \%$ at $1 / 75$ 
concentration and inhibition percentage $70.23 \%$ at 1/100. Finally the volatile Salvia officinalis oil and volatile oil of Zingiber officinale inhibited fungal growth with inhibition percentage $69.64 \%$ and $61.30 \%$, respectively, at 1/100 concentration (Table 2).

Table 2. Effect of different volatile oils on growth of fungi $C$. albicans

\begin{tabular}{|c|c|c|c|}
\hline Type of plant oil & $\begin{array}{c}\text { concentration } \\
\mathrm{cm}^{3} / \mathrm{cm}^{3}\end{array}$ & $\begin{array}{l}\text { Mean of colony } \\
\text { diameter } / \mathrm{cm}^{*}\end{array}$ & $\begin{array}{l}\text { percentage of } \\
\text { inhibition } / \%\end{array}$ \\
\hline \multirow[t]{4}{*}{ Apium graveolens oil } & $1 / 25$ & 1.8 & $78.57 \mathrm{E}$ \\
\hline & $1 / 50$ & 1.65 & $80.35 \mathrm{~B}$ \\
\hline & $1 / 75$ & 2.4 & $71.42 \mathrm{~L}$ \\
\hline & $1 / 100$ & 2.5 & $70.23 \mathrm{M}$ \\
\hline \multirow{4}{*}{$\begin{array}{c}\text { Mentha piperita } \\
\text { oil }\end{array}$} & $1 / 25$ & 1.75 & $79.16 \mathrm{D}$ \\
\hline & $1 / 50$ & 1.85 & $77.97 \mathrm{~F}$ \\
\hline & $1 / 75$ & 2.15 & $74.04 \mathrm{I}$ \\
\hline & $1 / 100$ & 2.3 & $72.61 \mathrm{~K}$ \\
\hline \multirow[t]{4}{*}{ Salvia officinalis oil } & $1 / 25$ & 1.25 & $85.11 \mathrm{~A}$ \\
\hline & $1 / 50$ & 1.7 & $79.76 \mathrm{C}$ \\
\hline & $1 / 75$ & 1.9 & $77.38 \mathrm{G}$ \\
\hline & $1 / 100$ & 2.55 & $69.64 \mathrm{~N}$ \\
\hline \multirow[t]{4}{*}{ Zingiber officinale oil } & $1 / 25$ & 1.8 & $78.57 \mathrm{E}$ \\
\hline & $1 / 50$ & 2.05 & $75.59 \mathrm{H}$ \\
\hline & $1 / 75$ & 2.25 & $73.21 \mathrm{~J}$ \\
\hline & $1 / 100$ & 3.25 & $61.30 \mathrm{~N}$ \\
\hline Control & 0 & 8.4 & $0.0 \mathrm{O}$ \\
\hline
\end{tabular}

* : Average values represent an average of three readings.

**: The values that share a single alphabetical letter have no significant difference according to the Duncan test at a probability level of 0.05 .

Table (3) indicates the inhibitory effect of volatile oils extracted from different medicinal plants on the growth of T. rubrum, In which the volatile oil extracted from the leaves of Salvia officinalis significantly exceeded the concentrations of $1 / 25$ and 1/50, with the percentage of inhibition $96.42 \%$ and $95.83 \%$ respectively, Followed by Zingiber officinale oil with $92.26 \%$ at concentration 1/25and Salvia officinalis oil at $1 / 75$ with $89.28 \%$. The oil of the leaves of the Apium graveolens and Zingiber officinale showed a different inhibitory effect of $85.11 \%$ and $82.73 \%$ at concentration $1 / 25$ and $1 / 50$, The percentage of Mentha piperita oil $81.54 \%$ did not differ at 1/25 concentration with Salvia officinalis effect at concentration 1/100, The effect of Apium graveolens volatile oil, Mentha piperita volatile oil and volatile oil of Zingiber officinale was similar to the inhibition percentage $79.76 \%$ respectively at concentrations $1 / 50,1 / 50$ and 1/75 while the concentration 1/75 and 1/100 of the volatile oil of the Apium graveolens were affected by $79.16 \%$ and $78.57 \%$, respectively, The percentage of inhibition of fungal growth was $77.97 \%$ for the volatile oil of Zingiber officinale at concentration 1/100. The 
Journal of Education and Science (ISSN 1812-125X), Vol: 30, No: 3, 2021 (21-33)

Special Issue for Proceeding of $3^{\text {rd }}$ National (1 ${ }^{\text {st }}$ international conference of biology) (ICBSUM 2021) 5, 6 July

College of Education for Pure Science, University of Mosul, Mosul, Iraq.

concentration of 1/75 and 1/100 of the volatile oil for Mentha piperita leaves was the lowest of the different concentrations, as the growth of T. rubrum was increased by $77.38 \%$ and $70.23 \%$ respectively.

Plants have been an important source of medicines since the dawn of human civilization. Despite the tremendous development in the field of morbidity during the 20th century, plants remain one of the major sources of medicine in the modern and traditional system of medicine throughout the world [20] [21]. Aromatic oils and secondary plant metabolism products have been widely applied in folk medicine, perfumery industries, food flavor and preservation, but only in recent years have begun to recognize their role as antimicrobial potential especially filamentous fungus Trichophyton mentagrophytes and Aspergillus fumigatus [22]. As well as determine the effects of essential herbal oils on human pathogenic fungi, especially Trichophyton spp. [23]. Mentha longifolia and Salvia fruticosa showed an inhibitory effect against all pathogens Trichophyton mentagrophytes

Table 3. Effect of different volatile oils on growth of fungi T. rubrum

\begin{tabular}{|c|c|c|c|}
\hline Type of plant oil & $\begin{array}{c}\text { concentration } \\
\mathrm{cm}^{3} / \mathrm{cm}^{3}\end{array}$ & $\begin{array}{l}\text { Mean of colony } \\
\text { diameter } / \mathrm{cm}^{*}\end{array}$ & $\begin{array}{l}\text { percentage of } \\
\text { inhibition } / \%\end{array}$ \\
\hline \multirow{4}{*}{$\begin{array}{c}\text { Apium graveolens } \\
\text { oil }\end{array}$} & $1 / 25$ & 1.25 & $85.11 \mathrm{E}$ \\
\hline & $1 / 50$ & 1.7 & $79.76 \mathrm{H}$ \\
\hline & $1 / 75$ & 1.75 & $79.16 \mathrm{I}$ \\
\hline & $1 / 100$ & 1.8 & $78.57 \mathrm{~J}$ \\
\hline \multirow{4}{*}{$\begin{array}{c}\text { Mentha piperita } \\
\text { oil }\end{array}$} & $1 / 25$ & 1.55 & $81.54 \mathrm{G}$ \\
\hline & $1 / 50$ & 1.7 & $79.76 \mathrm{H}$ \\
\hline & $1 / 75$ & 1.9 & $77.38 \mathrm{~L}$ \\
\hline & $1 / 100$ & 2.5 & $70.23 \mathrm{M}$ \\
\hline \multirow{4}{*}{$\begin{array}{c}\text { Salvia officinalis } \\
\text { oil }\end{array}$} & $1 / 25$ & 0.3 & $96.42 \mathrm{~A}$ \\
\hline & $1 / 50$ & 0.35 & $95.83 \mathrm{~B}$ \\
\hline & $1 / 75$ & 0.9 & $89.28 \mathrm{D}$ \\
\hline & $1 / 100$ & 1.55 & $81.54 \mathrm{G}$ \\
\hline \multirow{4}{*}{$\begin{array}{c}\text { Zingiber officinale } \\
\text { oil }\end{array}$} & $1 / 25$ & 0.65 & $92.26 \mathrm{C}$ \\
\hline & $1 / 50$ & 1.45 & $82.73 \mathrm{~F}$ \\
\hline & $1 / 75$ & 1.7 & $79.76 \mathrm{H}$ \\
\hline & $1 / 100$ & 1.85 & $77.97 \mathrm{~K}$ \\
\hline Control & 0 & 8.4 & $0.0 \mathrm{~N}$ \\
\hline
\end{tabular}

$*:$ Average values represent an average of three readings.

** : The values that share a single alphabetical letter have no significant difference according to the Duncan test at a probability level of 0.05 .

and Aspergillus fumigatus [24]. Salvia species have long been described in traditional medicine for various indicators. Because of the widespread prevalence of this type of plant by the ethnic population, especially for the various infections ranging from skin diseases and gastrointestinal disorders, Salvia 
Journal of Education and Science (ISSN 1812-125X), Vol: 30, No: 3, 2021 (21-33)

Special Issue for Proceeding of $3^{\text {rd }}$ National (1 ${ }^{\text {st }}$ international conference of biology) (ICBSUM 2021) 5, 6 July College of Education for Pure Science, University of Mosul, Mosul, Iraq.

officinalis oil showed an adverse effect on reverse dermatophyte and Aspergillus strains [25], S. rhytidea can also be effective against fungal infections. In view of the increased occurrence of candidiasis in the past decade, limitations on the use of antifungal drugs, the appearance of oxidative-resistant candidiasis and increased treatment failures, it is necessary to identify novel agents with antifungal properties. The results of phytochemical analysis showed that $S$. rhytidea extract was used. It was rich in flavonoids and tannins. The minimum inhibitory concentration (MIC) and the minimum inhibitory concentration (MIC) and minimum fungicidal concentration (MFC) values of $S$. Rhytidea ranged from 3.125 to> $100 \mu \mathrm{g} / \mathrm{ml}$ and 6.25 to $>100 \mu \mathrm{g} / \mathrm{ml}$, respectively. The value of inhibition of growth was shown as C. tropicalis, $C$. krusei and C. albicans [26]. The composition and antifungal activity of Salvia officinalis was also studied. On dermatophytes and Aspergillus [27]. Essential oils of red thyme, fennel, cloves, pine, sage, lemon and lavender balm is an inhibitory effect for the growth of clinical and environmental fungal strains [22]. Zingiber officinale is a medicinal plant that has been widely used in Chinese herbal medicines [28]. Plant extracts of Zinigiber officinale showed inhibitory growth of Aspergillus niger and Aspergillus flavus [29] [30], Zingiber officinale also showed antioxidant and antimicrobial activities against Aspergillus niger and Candida albicans [31].

\section{Conclusion}

The results indicate that the volatile oil extracted from the different medicinal plants used in this study has different inhibitory effects on the three fungi studied T. Mantagrophytes, T. rubrum and Candida albicans.

\section{References}

[1] R.R., Achterman and T.C., White. Dermatophyte virulence factors: Identifying and analyzing genes that may contribute to chronic or acute skin infections, Int. J. Microbiol. , 2012, 358305.

[2] M. A., Ghannoum; L.A., Wraith;, B., Cai;, J., Nyirady and, N., Isham. Susceptibility of dermatophyte isolates obtained from a large worldwide terbinafine tinea capitis clinical trial, Br. J. Dermatol., 159, 2008, Pp : 711-713.

[3] R.R, Achterman; A.R., Smith;, B.G., Oliver and, T.C., White. Sequenced dermatophyte strains: Growth rate, conidiation, drug susceptibilities, and virulence in an invertebrate model, Fungal Genet. Biol., 48, 2011, Pp : 335-341.

[4] M., Borgers;, H., Degreef and, G., Cauwenbergh. Fungal infections of the skin: Infection process and antimycotic therapy, Curr Drug Targets, 6, 2005, Pp : 849-862 . 
[5] T., Ishikawa;, F., Itoh; S., Yoshida; S., Saijo;, T., Matsuzawa; T., Gonoi; T., Saito; Y, Okawa.; N., Shibata andT., Miyamoto. Identification of distinct ligands for the C-type lectin receptors Mincle and Dectin-2 in the pathogenic fungus Malassezia. Cell Host Microbe.,13, 2013, Pp : 477-488.

[6] D.A., Martinez; B.G, Oliver; Y., Graser;, J.M., Goldberg; W., Li, N.M., Martinez-Rossi; M., Monod; E., Shelest; R.C., Barton and E., Birch. Comparative genome analysis of Trichophyton rubrum and related dermatophytes reveals candidate genes involved in infection. M. Bio., 3, 2012, Pp: 00259-00212

[7] O.M., Kekki; A, Scheynius.; S., Poikonen; A., Koskinen; H., Kautiainen and K., Turjanmaa.Sensitization to Malassezia in children with atopic dermatitis combined with food allergy. Pediatr Allergy Immun., 24, 2013, Pp : 244-249 .

[8] N.O., Ponde; L., Lortal, G., Ramage; J., Naglik and J.P., Richardson. Candida albicans biofilms and polymicrobial interactions. Critical Reviews in Microbiology, 47, 2021, 91 - 111. $10.1080 / 1040841 X .2020 .1843400$

[9] Y., Yan; F., Tan; H., Miao; H., Wang and Y.Y., Cao.. Effect of shikonin against Candida albicans biofilms. Front Microbiol., 10, 2019 : 1085.

[10] T., Truong;, G, Zeng.; L., Qingsong; L. T., Kwang; C., Tong; F. Y., Chan; Y., Wang and C. J., Seneviratne. Comparative ploidy proteo-mics of Candida albicans biofilms unraveled the role of the AHP1 gene in the biofilm persistence against amphotericin B. Mol Cell Proteomics. 15(11), $2016: 3488-3500$.

[11] J., Wuyts; P., Van Dijck; M., Holtappels. Fungal persister cells: the basis for recalcitrant infections/ PLoS Pathog. 14(10), 2018, 1007301.

[12] S.N., Batool; R., Albollah and M., Fereshteh. Prevelence of Candida species in the oral cavity of patient with periodenititis. African J. Biotech. Vol. 10 (15), 2011, Pp.2987-2990.

[13] M.A., Pfaller; D.J., Diekema and R.N., Jones. Ternds in antifungal susceptibility of Candida spp. Isolated from perdiatric and adult patients with bloodstream infections: SENTRY Antimicrobial Surveillance Program, 1997 to 2000. J. Clin. Microbial., 40, 2000 :852-6.

[14] G.G., Haylen; G.M., Evelyn; Z., Olga; L.C., Maria; R.V., Sofia; R., Sandra and M., Luz. Oral candidiasis in children and adolescents with cancer. Identification of Candida species. Med. Oral Patol. Oral Cil. 1,12(6), 2007, Pp 23-419.

[15] T. A., Al-Tikrity. Evaluation of antifungal activity of some plants extracts against dermal fungi. M Sc. Thesis, College of Medicine, Tikrit Univ. Iraq, 1997.

[16] I. A., El-Kady;, S. S., Al-Maraghy and E. M., Mohammed. Antibacterial and antidermatophyte activities of some essential oils from spices, Qutar Univ. Sci. J. 13 (1), 1993 : 63-69. 
Journal of Education and Science (ISSN 1812-125X), Vol: 30, No: 3, 2021 (21-33)

Special Issue for Proceeding of $3^{\text {rd }}$ National (1 ${ }^{\text {st }}$ international conference of biology) (ICBSUM 2021) 5, 6 July

College of Education for Pure Science, University of Mosul, Mosul, Iraq.

[17] J., Vandepitte; K., Engback; P., Poit and C., Heuk. Basic "Laboratory procedures in clinical Bacteriology World Health Organixation", Geneva, 1991.

[18] M., Leven; D. A., Vanden Berghe; F., Merten; A., Vlietinke and E., Lammens. Antibacterial activity plants media, 36, $1997: 311-321$.

[19] M. D., Neda; B., Biljana; S., Marina and S., Natasa.Antimicrobial and Antioxidant Activities of Melissa officinalis L. (Lamiaceae) Essential Oil, J. Agric. Food Chem., 52 (9), 2004, pp : 2485-2489.

[20] A. M., Salman and A. E., Hasan. Efficiency of some plant extracts, Bacillus Cereus and antibiotics on control the rot disease on potato caused by Erwinia carotovora subsp. Carotovora, J. Khofa for Agricultural sciences, V. 3 (2), 2011 : 151 -161.

[21] A., Chudiwal; D., Jain, and R., Somani. Alpinia galanga Willd.- An overview on phytopharmacological properties. Indian Journal of Natural Products and Resources, 1, 2010, 143 149.

[22] V., Tullio; A., Nostero; N., Mandras; P., Dugo; G., Banche; M . A., Cannatelli; M., Cuffini; V., Alonzo and N. A., Carlon. Antifungal activity of essential oils against filamentous fungi determined by broth microdilution and vapour contact methods, Journal of Applied Microbiology, V. 102, Issue 6, 2007, Pp : $1544-1550$.

[23] S., Shin and, S., Lim .Antifungal effects of herbal essential oils alone and in combination with ketoconazole against Trichophyton spp., Journal of Applied Microbiology, V. 97, Issue 6, 2004, Pp : 1289-1296.

[24] Y., Abou-Jawdah; H., Sobh and A., Salameh. Antimycotic Activities of Selected Plant Flora, Growing Wild in Lebanon, against Phytopathogenic Fungi, J. Agric. Food Chem., 50 (11), 2002, pp 3208-3213

[25] M.S, Abu-Darwish; C., Cabral; I.V., Ferreira; M.J., Gonçalves; C., Cavaleiro; M.T. , Cruz; T.H, Al-bdour and L., Salgueiro .Essential oil of common sage (Salvia officinalis L.) from Jordan: assessment of safety in mammalian cells and its antifungal and anti-inflammatory potential, Biomed Res Int.:538940. doi: 10., 2013. 1155/2013/538940.

[26] S. S., Panel; T., Bakhshi; F., Sharififar; A., Naseri; P., Ghasemi and N., Almani. Evaluation of antifungal activity of standardized extract of Salvia rhytidea Benth. (Lamiaceae) against various Candida isolatesÉvaluation de l'activité antifongique d'extrait standardisé de Salvia rhytidea Benth. (Lamiaceae) contre divers isolats de Candida. Journal de Mycologie Médicale, V. 26, Issue 4, 2016, Pp : 323-330.

[27] P., Eugénia; S., Lígia Ribeiro; C., Carlos; P., Ana and J.G., Maria. In vitro susceptibility of some species of yeasts and filamentous fungi to essential oils of Salvia officinalis, Industrial Crops and Products, V. 26, Issue 2, 2007, Pp. 135-141. 
Journal of Education and Science (ISSN 1812-125X), Vol: 30, No: 3, 2021 (21-33)

Special Issue for Proceeding of $3^{\text {rd }}$ National (1 ${ }^{\text {st }}$ international conference of biology) (ICBSUM 2021) 5, 6 July College of Education for Pure Science, University of Mosul, Mosul, Iraq.

[28] H., Badreldin; G. B., Ali; O., Musbah and A. N., Tanira .Some phytochemical, pharmacological and toxicological properties of ginger (Zingiber officinale Roscoe): A review of recent research, Food and Chemical Toxicology, V. 46, Issue 2, 2008, Pp. 409-420.

[29] R .N., Okigbo and I. A., Nmeka. Control of yam tuber rot with leaf extracts of Xylopia aethiopica and Zingiber officinale, African Journal of Biotechnology Vol. 4 (8), 2009, pp: 804-807.

[30] S., Gurdip;, M. P., Om Prakash Singh; x C., Om Prakash and A. N., Catalán. Studies on essential oils, Part 42: chemical, antifungal, antioxidant and sprout suppressant studies on ginger essential oil and its oleoresin, Flavour and Fragrance Journal, V. 20, Issue 1, 2005, Pp : 1-6.

[31] B., Yuva. Total antioxidant activity and antimicrobial potency of the essential oil and oleoresin of Zingiber officinale Roscoe, Asian Pacific Journal of Tropical Disease, Volume 4, Issue 1, 2014, Pp : 40-44. 